\title{
多变量解析による多項目臨床化学データーの解析
}

\section{（第 3 報） 主成分分析法に上る多項目健常域設定の試み}

\author{
○佐藤信彦* 平岡龍男* 内田壱夫* 若林正雄*
}

現在, 血清中の化学諸成分を多種目について, 測定す ることにより, 診療, 治療での重要な判断基準の一つの 情報となってきている。その判断基準の重要な尺度とし て, 単変量の健常域が, 集団及び個体から算定され, 使 用されている。

近年, 測定方式も従来から行なわれていた用手法にか かわり, コンピューターを内臓, 接続し, 数多くの検査 項目を同時に分析し，かつ，データ一解析をも可能な多 項目同時分析機の普及に伴い，その同時分析の特性や， その分析機などの持つシステムの特徴なども，考慮した 健常域設定が，大きな課題の一つである。

又, 生体中の諸成分は, 互いに何らかの, 関連する事 により, 規則性, 恒常性を保ちつつ変動している。多項 目同時分析の持つ一つの大きなメリットとして, それら の成分に対しての測定であるから, 規則性, 恒常性を重 視し，その数量的な変換を行い，一つの健常域として利 用されるために，多变量解析法の主成分分析法を使用 し, その多変量健常域設定々, その有用性を検討した。

又, 今回は, Patient Population からの抽出集団に 対しての処理を行い, その処理過程の有用性をも, 検討 した。

\section{処理過程}

今回の処理過程は, 母集団に対して, 各分析項目每に, 仮健常域を設定し，その範囲内で抽出し，その抽出集団
での各分析項目の分布型の正規性の検定を行う。又, 変 数変換も行い, AIC (赤池の情報量規準) や，その他の 統計量を併用し, 正規分布に近い变数变換を決定し, 次 に，収斂法を採用する。

以下, 前記の手法をくりかえし, Patient Population から，健常集団を抽出した後，主成分分析を行なった。

\section{結 論}

今回の処理過程における妥当性を CHECK するため に，集団検診（約 2 千例）と，今回使用しなかった Patient Population（約 2 万例）について，再現性を check し，良好な結果を得た。

又, 今回の主成分值応用による健常域についてのメリ ットは,

1) 検査項目において, 総合的な評価が, 客観的に行 える。

2 ) 従来から問題となっている個人の生理的変動をも 含んだ健常域設定の可能性がある。

3 ）検查項目間の論理的な測定ミスも， check でき る。

4 ) Patient Population からの, 健常域設定が可 能 である。

5 ) 病患者群を判別することができ, 又, 性, 年齢 や，その他の因子も判別できる可能性がある。

Multivariate data analysis A trial of establisment of normal ranges for multiple analyzed items by principal components analysis

* 日本医学研究所 